\title{
Diet-induced obesity aggravates NK cell-mediated contact hypersensitivity reaction in $\operatorname{Rag} 1^{-/}$mice
}

\author{
Paulina Kowalczyk ${ }^{1}$, Monika Majewska-Szczepanik ${ }^{1}$, Anna Strzępa ${ }^{1}$, Dominika Biała ${ }^{1}$, and \\ Marian Szczepanik ${ }^{2}$ \\ ${ }^{1}$ Uniwersytet Jagiellonski Wydzial Nauk o Zdrowiu \\ ${ }^{2}$ Uniwersytet Jagielloński Wydział Nauk o Zdrowiu
}

September 11, 2020

\begin{abstract}
BACKGROUND: Previous studies showed that liver NK cells mediate contact hypersensitivity (CHS) reaction in mice. There are many reports showing that obesity is accompanied with chronic low-grade inflammation and it promotes several inflammatory diseases. It was shown that diet-induced obesity (DIO) aggravates classical T cell-mediated CHS in C57BL/6 mice. Our work sheds light on a poorly explored subject of the influence of DIO on the course of NK cell-mediated CHS reaction in mice. METHODS: We evaluated the effect of DIO on NK cell-mediated CHS reaction using a model of dinitrofluorobenzene (DNFB)-induced CHS in Rag1-/- mice. RESULTS: Our data show that mice fed HFD for 8 but not for 4 weeks developed aggravated CHS reaction determined by ear swelling measurement when compared to animals kept on normal diet (ND) prior to DNFB sensitization. The obese $\operatorname{Rag}^{-/-}$mice presented the adipose tissue inflammation. Furthermore, in vitro analysis showed that feeding with HFD significantly increases IFN- $\gamma$ and IL-12p70 and decreases adiponectin concentration in liver mononuclear cells (LMNC) culture supernatants. The flow cytometry analysis of LMNC revealed that HFD treatment prior to DNFB sensitization increases the percentage of $\mathrm{NK} 1.1^{+} \mathrm{IFN}-\gamma^{+}$cell population and affects development and maturation of NK1.1 ${ }^{+}$cells. CONCLUSION: In summary, current results suggest that the DIO significantly modulates the local and systemic inflammatory response, contributing to exacerbation of the CHS response mediated by liver NK cells.
\end{abstract}

\section{Hosted file}

manuscript_Kowalczyk.pdf available at https://authorea.com/users/358363/articles/480537diet-induced-obesity-aggravates-nk-cell-mediated-contact-hypersensitivity-reaction-inrag1-mice 


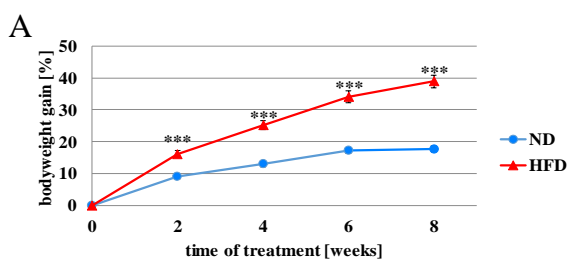

B

C
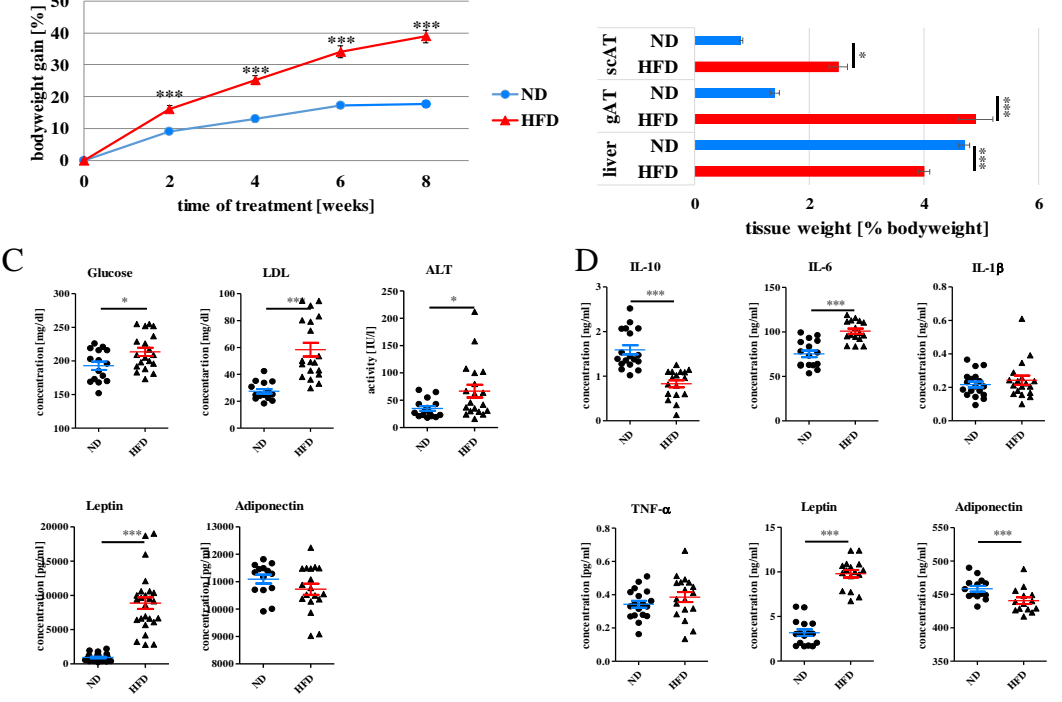

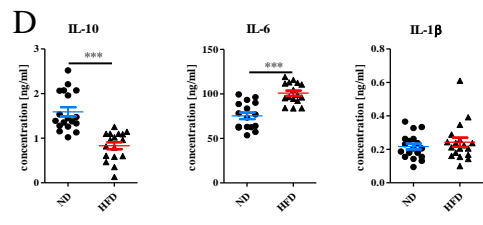

A

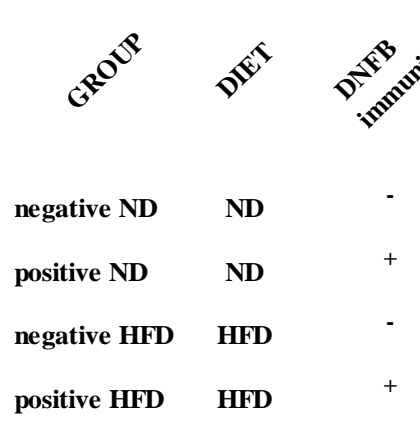

B

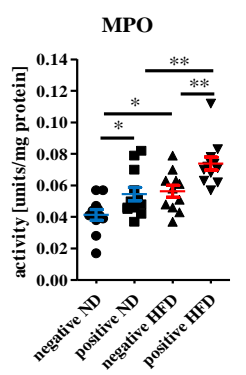

C

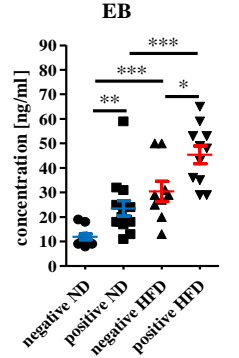<smiles>[13CH3]</smiles>

Contact hypersensitivity (CHS)

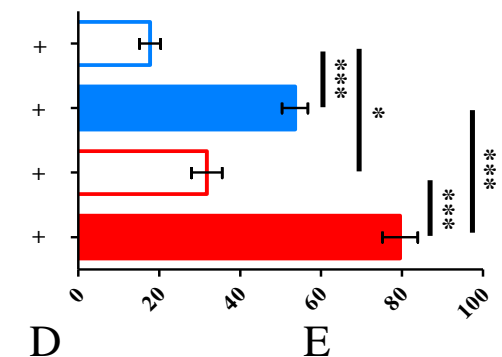

D ${ }_{\text {IFN- } y}$

IL-10

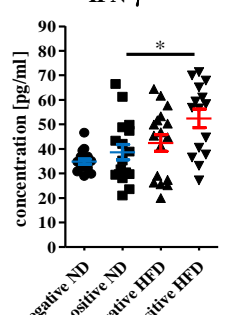



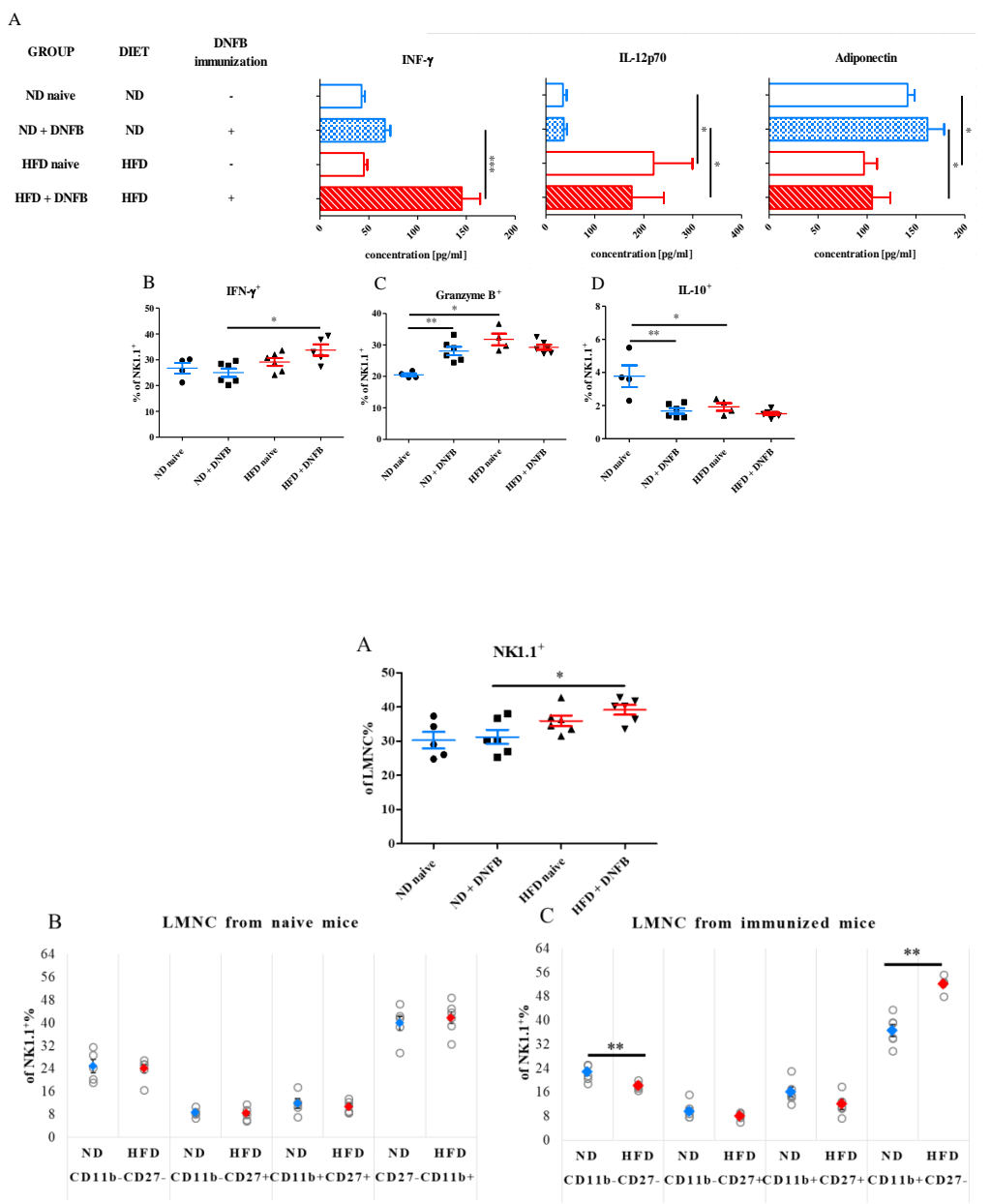